\title{
A situation of ethical limbo and preimplantation genetic diagnosis
}

Tomasz Żuradzki

\begin{abstract}
In my previous paper I argued that if in vitro fertilization (IVF) is legal and practiced there is no moral ground to object to legalization of preimplantation genetic diagnosis (PGD). My opponent raises an objection that my paper "fails to address the ethical argumentation of one key opponent of IVF - the Catholic Church". In this reply I show that her/his thesis that embryos created during IVF are in 'ethical limbo' and "fall outside the moral universe of Christian ethics" does not undermine my argumentation and masks the serious problem Catholics have with the moral status of early embryos.
\end{abstract}

I start with a short info about the context of my previous paper, since it is relevant for this discussion and, as my opponent notices, I am "a bioethicist in a country where the statements of the Catholic Church have significant impact on medico-ethical policy."[1] In 2012 the Bioethics Committee of the Polish Academy of Sciences produced an Opinion calling for the regulation of PGD (now it is not regulated but practiced). Some members of the Committee objected to the Opinion invoking their pro-life views. If their position were accepted by the legislator, PGD would be illegal, although IVF, prenatal diagnosis and the termination of pregnancy in some rare cases (e.g. when there is a great probability that a future child will suffer from an irreversible and serious disease) are legal. This could lead to absurd situations when an embryo implanted during the IVF procedure could be legally aborted, because of genetic illness that could have been tested during PGD. I assumed that this legal solution would be hard to swallow for everyone, no matter which moral views she or he subscribes to. So I proposed a universal argument claiming that if IVF is legal and practiced there is no moral ground to object legalization of PGD.[2]

My critic cites Dignitas Personae (DP), the key document of the Catholic Church on bioethics published in 2008. It claims that "the thousands of abandoned embryos represent a situation of injustice which in fact cannot be resolved."[3] In my opponent's opinion I miss "this nuance in the Church's writings" that early embryos are in a situation of 'ethical limbo' (the phrase of my opponent), "their ontological status is so removed from the natural order that they fall outside the moral universe of Christian ethics" and "the absurd existential state 
of the embryo... vitiates any moral obligation". The opponent concludes that "an orthodox Catholic would not be obliged to choose PGD" and has a moral duty not to facilitate PGD.[1]

Let me start with a clarification: strictly speaking an orthodox Catholic "would not be obliged to choose PGD", because this possibility would never have arisen for someone who perceive IVF as deeply morally wrong. IVF is unambiguously condemned by the Catholic Church, because it (i) involves the deliberate destruction of nascent human life; (ii) "dissociate[s] procreation from the integrally personal context of the conjugal act"; (iii) and cryopreservation is "incompatible with the respect owed to human embryos" [3]. My argument was meant not to help solving moral dilemmas by an orthodox Catholic but finding a policy acceptable on all moral frameworks (my opponent notices this aim in the last sentence). I argued that even an orthodox Catholic does not have any moral ground to oppose the legalization of PGD in a legal system where IVF is legally permissible.

It is surprising why my critic cites the fragment of DP on "the thousands of abandoned embryos", since my argument refers to embryos before the implantation procedure, not to embryos left over from IVF. The problem of 'abandoned embryos' is discussed in DP in a quite different context: whether married couples ought to "adopt" them. So my opponent assumes that embryos before implantation are in the same "absurd existential state" as embryos left over from IVF without any textual basis for this claim in DP.

Moreover, DP gives two immediate reasons why PGD is immoral. PGD is supposed to be "directed toward the [i] qualitative selection and [ii] consequent destruction of embryos".[3] My argument shows that these two direct reasons do not work even for an orthodox Catholic: [ii] is irrelevant, because spare embryos will die anyway no matter which selection method we choose; [i] "qualitative selection" which supposed to be "the expression of a eugenic mentality" cannot be always morally wrong, since it would be preferred by embryos themselves. My opponent replies that the Catholic ethic would demand to ignore these kind of preferences and compares them with the wish for abortion. But these cases are completely different: abortion involves destroying a being with full moral status according to Catholic doctrine; a hypothetical preference to live longer rather than shorter in my case is not conditional on imposing any additional harm.

My opponent presents an additional reason why PGD is morally wrong: [iii] embryos created during IVF are in 'ethical limbo' so no standard norms of Christian ethic do not apply to them. As it is not morally permitted to adopt abandoned embryos according to DP (although it seems that it should be morally obligatory if we treat embryos as persons childhood adoption, after all, is encouraged by the Church), so it is not morally permitted to select embryos in the PGD procedure.

Firstly, it is not clear what does it even mean to be 'ethical limbo' or "fall outside the moral universe of Christian ethics". After all my opponent does not hesitate to voice her/his opinion in this matter and suggests that a Catholic has a moral duty not to facilitate PGD. 
Secondly, even if Catholics accept that embryos produced during IVF are in 'ethical limbo', does it give reasons to call on ban on PGD? Surprisingly, the reasons seem to be much weaker if we assume that embryos are in ethical limbo with the comparison to a standard interpretation of the Catholic view (early embryos have full moral status and should be treated in exactly the same way as persons). So a key question is not answered by my opponent: why do orthodox Catholics insist that people who decide on IVF should rely on pure luck and not on PGD when selecting embryos for implantation?

Two important lessons can be learned from this discussion. Catholics mix arguments against the legalization of IVF (which are quite obvious, assuming their pro-life views) with arguments against the legalization of PGD in a situation when IVF is legal and performed. More important is the fact that the pro-life view is not as straightforward as it is commonly believed. In particular the Catholic Church does not claim that early embryos are persons, but only that they deserve "the dignity proper to a person".[3] I argued elsewhere this position is based not on presumptions about the ontological status of embryos but on the specific criteria of rational decisions under uncertainty. [4, 5]

\section{Funding}

The research was supported by a grant 'luventus Plus' funded by the Polish Ministry of Science and Higher Education (no. IP2011065171).

\section{References}

1. Symmons X. Response to Tomasz Żuradzki's 'Preimplantation genetic diagnosis and rational choice under risk and uncertainty'. Journal of Medical Ethics 40/11 (2014): 779

2. Żuradzki T. Preimplantation genetic diagnosis and rational choice under risk or uncertainty. Journal of Medical Ethics, 40/11 (2014): 774-8.

3. Congregation for the Doctrine of the Faith. Instruction Dignitatis Personae on certain bioethical questions. 2008. http://www.vatican.va/roman_curia/congregations/cfaith/documents/rc_con_cfaith _doc_20081208_dignitas-personae_en.html (accessed 15 July 2014)

4. Żuradzki T. Argument z niepewności normatywnej a etyczna ocena badań naukowych wykorzystujących ludzkie embriony. Diametros 32 (2012): 131-59

5. Żuradzki T. Moral uncertainty in bioethical argumentation: a new understanding of the 'pro-life' view on early human embryos. Theoretical Medicine and Bioethics 35/6 (2014): 441-457 